\title{
Juvenile Type Granulosa Cell Tumor
}

National Cancer Institute

\section{Source}

National Cancer Institute. Juvenile Type Granulosa Cell Tumor. NCI Thesaurus. Code C4207.

A granulosa cell tumor occurring in the ovary and testis. In females it occurs predominantly in the first three decades of life and presents unilaterally as stage I disease in the vast majority of cases. It is characterized by the presence of granulosa cells forming macrofollicular structures. The majority of cases have a good prognosis. In males it represents the most frequent congenital testicular neoplasm and the vast majority of cases occur in the perinatal period. It presents as a scrotal or abdominal mass and it more often affects the left testis. Approximately $20 \%$ of the patients have ambiguous external genitalia. It is characterized by the presence of cystic spaces lined by granulosa cells and cells resembling theca cells. Metastases have not been reported. 